\title{
Impacts of Addition of Palm Kernel Shells Content on Mechanical Properties of Compacted Shale Used as an Alternative Landfill Liners
}

\author{
Clement A. Amagu (D), ${ }^{1}$ Beatrice O. Enya, ${ }^{2}$ Jun-ichi Kodama, ${ }^{1}$ and Mostafa Sharifzadeh ${ }^{3}$ \\ ${ }^{1}$ Rock Mechanics Laboratory Graduate School of Engineering, Hokkaido University, Kita-ku 0608628, Sapporo, Japan \\ ${ }^{2}$ Department of Geology, University of Ibadan, Ibadan, Nigeria \\ ${ }^{3}$ Key Laboratory of Ministry of Education for Safe Mining of Deep Metal Mines, Northeastern University, \\ Shenyang 110819, China \\ Correspondence should be addressed to Clement A. Amagu; amaguclementglk@gmail.com
}

Received 3 November 2021; Revised 7 January 2022; Accepted 17 January 2022; Published 21 February 2022

Academic Editor: Md. Akter Hosen

Copyright (c) 2022 Clement A. Amagu et al. This is an open access article distributed under the Creative Commons Attribution License, which permits unrestricted use, distribution, and reproduction in any medium, provided the original work is properly cited.

\begin{abstract}
The design of landfill liners of waste disposal to reduce migration of leachate containment, low swelling, and shrinkage and ensure sufficient shear strength to resist bearing capacity and instability of the landfill has been a major challenging task to landfill engineers. Over the last decade, there has been an increase in research on the stability of substitute materials as liners that are environmentally friendly, cost-effective, and socially beneficial due to the growing cost of traditional landfill liners. In this regard, geotechnical tests were conducted on shale samples treated with $0-12 \%$ (increment of $2 \%$ ) of palm kernel shell ash (PKSA) and pulverized palm kernel shell (PPKS) to evaluate their suitability as alternative landfill liners using West African Standard (WAS) and Modified AASHTO Standard (MAS) for compactive energy. The shale has more percentage of finer fractions, thus classified as poorly graded soil (A-7-5). The Atterberg limit tests show that liquid and plastic limits decrease with an increase in plasticity index as the percentage of addition of PKSA and PPKS content increases. The results also established that the maximum dry density (MDD), volumetric shrinkage strain (VSS), and hydraulic conductivity significantly decrease, while the optimum moisture content (OMC) increases as the content of PKSA and PPKS increases at both compactive efforts. The maximum strengths of 380.30 and $448.70 \mathrm{kPa}$ were obtained at $4 \%$ of both stabilizers. From the results, it can therefore be concluded that the treated compacted shale meets the condition of the suitability of landfill liners. Furthermore, with the use of industrial and agricultural wastes such as palm kernel shells as replacement materials with natural soils used as liners, significant social, economic, and environmental impact of landfills and reduction in wastes can be achieved. The research results can provide a reference for similar conditions of landfill liners worldwide.
\end{abstract}

\section{Introduction}

To date, there is a global increase in waste generation as a result of growth in population and income, changing lifestyles, increase in industrialization and use of disposable materials, excessive packaging of items, and consumer's habits. Daily, domestic and industrial wastes are generated in large quantities and the safe disposal of these waste materials is increasingly becoming a major concern around the world. Currently, waste is becoming more serious than ever as there are lots of environmental problems related to its management.
Further, landfilling of wastes has been the final stage of many municipal wastes in many countries $[1,2]$. It confines the waste to the available area, thereby reducing the waste to the minimum practical volume. Despite that, the problem of waste management is still a big social and environmental issue complying with the shortage of landfill capacity, a result of doubt to the environmental soundness of landfills and reject to unpleasant landfills [3], mainly because the waste in a landfill often reacts to release leachate, which poses a threat to the surrounding environment and humans [3]. Hence, the environmental impacts of landfills are 
numerous, including the contamination of surface water and groundwater by leachate, pollution of soil by direct contact with wastes or leachate percolation, spreading of diseases and foul odours in landfill areas, and uncontrolled release of methane by anaerobic decomposition of deposited wastes $[4,5]$.

To overcome these problems, waste disposal of landfills should be packaged and placed in an underground vault surrounded by thick liners to provide a certain degree of redundancy for leachate containment [1]. In particular, Kayabaly [6] and Cazaux and Didier [7] reported that liners are required to minimize pollutant migration over the long term, low swelling and shrinkage, and resistance to shearing. As a matter of fact, landfill liners must have a large attenuation capacity to prevent seepage of leachate into the surrounding groundwater and subsequent contamination of the groundwater system [7].

For these reasons, liners must be designed to accommodate the landfill settlement, lower the hydraulic conductivity, and have sufficient shear strength to resist bearing capacity and slope failure [8]. Over the last decades, compacted clay liners, bentonite, or bentonite-bearing mixtures have been used extensively in constructing landfills due to their cost-effectiveness and large capacity of attenuation $[6,8]$. In spite of that, these barriers contain appreciable swelling clay minerals, e.g., smectites; thus, they have high shrinkage and high expansive potential causing instability problems [9]. Additionally, geosynthetic clay liners, geomembranes, geonets, and geotextiles are often used to construct liners in developed countries, even though they are more expensive [10-12].

From the above discussions, it can be said that the sustainability of clay liners may be significantly affected by their long-term sealing capabilities, resulting from the hydraulic conductivity after compaction, swell-shrinkage characteristics, resistance to cyclic drying and rewetting, and desiccation cracking [1]. Notwithstanding, the aforementioned liners are very uncertain in the design of landfills in low- and mediumincome countries, such as Nigeria, mainly because there might be a possibility of social unacceptability and lack of technological know-how to achieve the desired purposes. Therefore, the stabilization of natural soils used as liners with recycled or waste materials, such as oil palm ash, shell and clinker, rice husk ash [13], coconut shells [14], iron ore tailings, and blast furnace slags [15], has been a way to forward alternative solutions in the landfill engineering to ensure the significant social, economic, and environmental impact of landfills, consequently ensuring that the high mechanical strength, impermeability to water, stability, and great durability of the landfills are also achievable. Therefore, the investigations of the stabilizing potential of industrial and agricultural waste in soils have become the focus of research globally. Hence, the need for the use of palm kernel shell, which is relatively inexpensive and readily available locally through the burning and grinding of palm kernel shell as a stabilizing agent to enhance the mechanical properties of natural soils used as landfill liner, has become very significant [16].

In Nigeria, approximately $64 \%$ of palm kernel shell is generated as waste per year [17]. The palm kernel shell is regarded as waste from oil processing, which is either burnt to supply energy at palm oil mills or left in piles to compost. This in turn pollutes the environment. Thus, it is greatly required to consider the use of palm kernel shell in improving the engineering properties of natural soil liners in landfill sites. Thus, the main aim of this study is to evaluate the suitability of compacted shale treated with palm kernel shell ash (PKSA) and pulverized palm kernel shell (PPKS) as an alternative material for landfill liners. The hydraulic conductivity, swell-shrink characteristics, and geotechnical properties of the compacted shale samples treated with the two selected stabilizers were examined using West African Standard (WAS) and Modified AASHTO Standard (MAS) for compactive efforts to ascertain their potential usage as an engineered barrier in waste containment applications. This approach can also serve as an alternative disposal means of palm kernel shells in Nigeria.

\section{Environmental Issues of Open Dumping Site in Nigeria}

Over the decades, prevention, reuse, recycling, recovery, and disposal of waste in the practice of collecting, treating, and managing waste in Nigeria have been a challenging task as a result of the unchecked rapid growth of urban population, unplanned urbanization, changing lifestyles, increase in the use of disposable materials, lack of training in modern solid waste management practices, lack of awareness on the dangers of unsustainable waste management practices, poverty, illiteracy, and poor government policies $[1,18]$. In Nigeria, the generation, disposal, or management of waste has proved to be a major environmental and public health issue. Waste is often dumped on the major streets and several open spaces and left unattended for long periods (Figure 1), which encroach on the roads, thereby limiting road users access, generate serious air pollution issues, constitute a significant nuisance when blown over by the wind, and distort the aesthetic view of the metropolis [19]. Environmental and health issues arising from the unsustainable management of those open dumping waste sites have consequently resulted in runoff of toxic compounds into surface water and groundwater, which contaminates the water due to the percolation of leachate [20]. To overcome this problem, there is a need for sophisticated landfill technology to ensure that the waste is disposed of in a landfill, which is the simplest, cheapest, and most cost-effective method of disposing of waste [21]. Thus, the utilization of waste such as palm kernel shells to stabilize natural soil used as landfill liners is a priority because it is not only a cost-effective and already available material but also an alternative disposal means of palm kernel shells in Nigeria.

\section{Geological Characteristics of the Study Area}

The study area is located at Nguzu Edda in Afikpo South Local Government Area, Ebonyi State. Geographically, the area is bounded by longitude $7^{\circ} 49^{\prime} \mathrm{E}$ to $7^{\circ} 54^{\prime} \mathrm{E}$ and latitude $5^{\circ} 45^{\prime} \mathrm{N}$ to $5^{\circ} 50^{\prime} \mathrm{N}$, as depicted in Figure 2. The area lies within the Afikpo Subbasin, which is regarded as the 

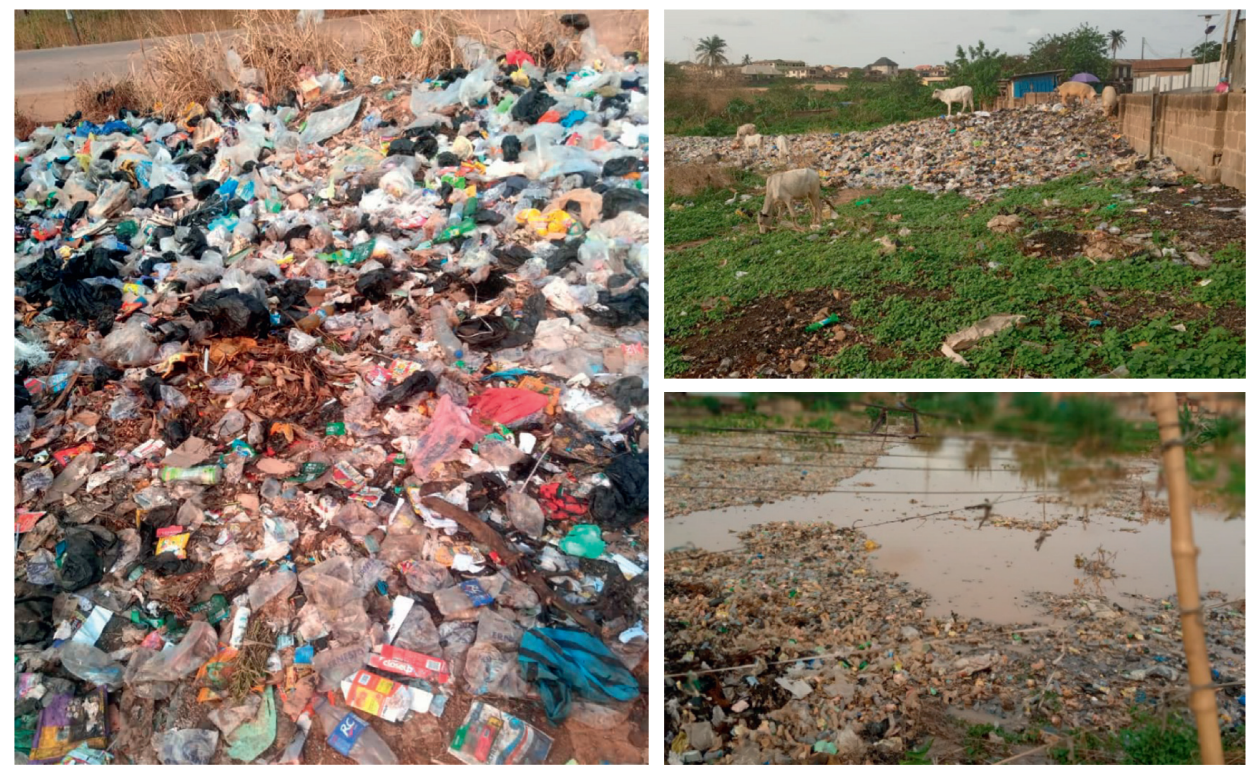

Figure 1: Picture of the open dumping site at Nguzu Edda.

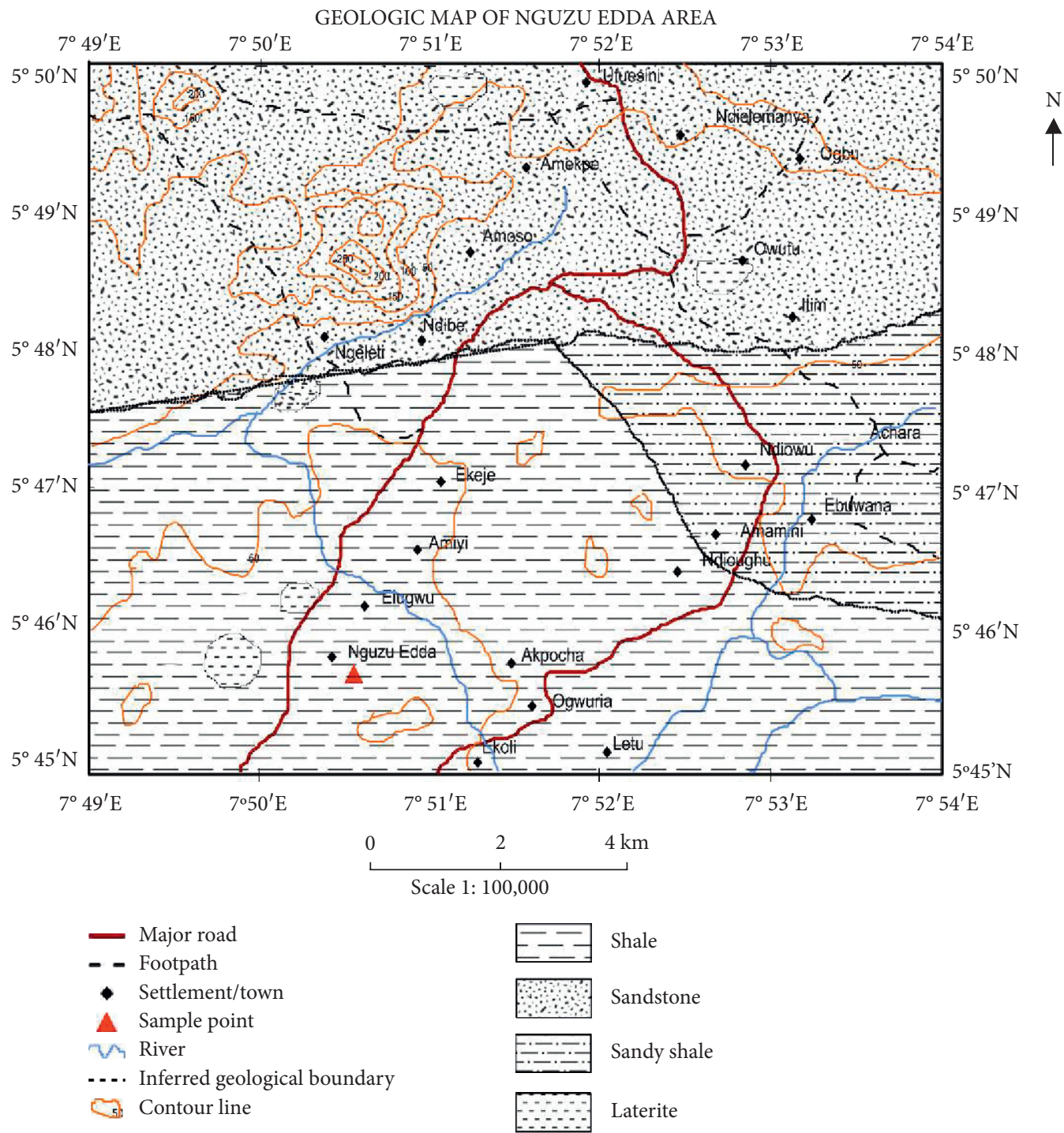

Figure 2: Geological map of the study area. 
southeastern depression of the Anambra Basin [22]. Stratigraphically, the study area is predominantly composed of the sediments of the Upper Campanian-Maastrichtian identified as the Afikpo sandstone, Nkporo, and Mamu Formation [23], which consists mainly of fine to very coarse ferruginized sandstone and shale with intercalations of sandstone and shale and laterite. The shale is soft and there is a precipitate of ironstone and sandstone interbeds on the shale. It has a thick pile of clay minerals, most likely to be kaolinite. The laterite of the area has been used for construction purposes mostly as fillings, both as subgrade for road and pavement construction and as filling in roads, buildings, and dam fillings.

\section{Materials and Methods}

The shale employed for this study were taken along Nguzu Edda road within longitude $7^{\circ} 50^{\prime} 38.3^{\prime \prime} \mathrm{E}$ and latitude $5^{\circ} 45^{\prime} 48.29^{\prime \prime} \mathrm{N}$ using both disturbed and undisturbed sampling methods at a square meter of $3 \times 3$ at $1 \mathrm{~m}$ depth. The palm kernel shells (PKS) were sourced from the local milling farm at Ugwuegu village. It was sorted and air-dried sufficiently. To generate palm kernel shell ash (PKSA), some of the palm kernel shells were burnt in a blast furnace to about $900^{\circ} \mathrm{C}$, whereas others were grounded as pulverized palm kernel shell (PPKS). The air-dried samples were sieved through a sieve aperture of $4.76 \mu \mathrm{m}$, while the palm kernel shell contents were sieved through a sieve aperture of $75 \mu \mathrm{m}$. Index properties of both the natural and shale-palm kernel shell mixtures were determined in accordance with British standard BS 1377 [24]. Two compaction energy levels, West African Standard (WAS) and Modified AASHTO Standard (MAS), were used for comparison purposes. The engineering tests such as optimum moisture content (OMC), maximum dry density (MDD), volumetric shrinkage strain (VSS), compressive strength, and hydraulic conductivity $(k)$ were carried out at the Soil Laboratory, Department of Geology, Federal University of Technology, Akure, Nigeria, to determine the suitability of the treated samples as landfill liners. The Atterberg limits, grain size distribution test, specific gravity, and natural moisture content tests were carried out on the natural shale samples at the laboratory of the Civil Engineering Department, University of Ibadan. The sieved air-dried soil samples were batched using $0,2,4,8$, and $12 \%$ PKSA and PPKS by dry weight. Rigid wall permeameter under falling head condition was used for hydraulic conductivity, the samples for compressive strength test were cured for 3 days prior to the test, while the samples for drying shrinkage test were cured for a day, thereafter, extruded, and cured for a period of 30 days. The measurements of diameters and heights for each specimen were taken with the aid of a vernier caliper of accuracy of $\pm 0.03 \mathrm{~mm}$.

\section{Results and Discussion}

5.1. Analysis of the Index Properties of the Untreated Shale. The results of index tests such as Atterberg limits (liquid and plastic limits), particle size distribution, natural moisture content, specific gravity test, compressive strength, hydraulic conductivity, and volumetric shrinkage strain carried out on the shale sample are presented in Table 1 for comparison with the treated shale samples as described in the later sections. Figure 3 shows the grading curve of the particle size distribution of the shale. As can be seen from Figure 3, there is clear evidence that the shale had more fine fractions than the coarse fractions. From Table 1 and Figure 3, the results showed that the shale samples have more percentage of finer fractions that pass $0.075 \mathrm{~mm}$ sieve, $<35 \%$ with LL of $56.60 \%$ and PI of $21.29 \%$. Overall, the shale has significant constituent materials, mainly clay, silty, gravel, and sand. From this point of view, the shale was classified as poorly graded soil (A-7-5) and $\mathrm{MH}$ according to the American Association of State Highway Transportation Officials (AASHTO M 145) [25] and Unified Soil Classification System (USCS), respectively. Figure 4 shows the Casagrande chart of the shale, which indicates that the samples are widely distributed in the region of high plasticity below the A line of the Casagrande chart. The high plasticity could be explained by the presence of the fine fraction, which tends to reduce the interconnected pores. Consequently, the high plasticity index can reduce hydraulic conductivity, implying that the shale can withstand volumetric shrinkage on drying and exhibit a low to medium swelling potential when wet. It is worth noting that the fine fractions are expected to help in the workability, while the coarse fractions enhance the mechanical strength of the shale. Hence, the shale is expected to resist an increase in hydraulic conductivity that may be caused by the contaminant and also retard the migration of contaminants through sorption [26].

5.2. Atterberg Limits Test. Atterberg limit tests were conducted to determine the liquid limit (LL), plastic limit (PL), and plasticity index (PI) of shale treated with $0,2,4,8$, and $12 \%$ of palm kernel shell ash (PKSA) and pulverized palm kernel shell (PPKS) by dry weight of the samples. Figure 5 shows the effects of the addition of PKSA and PPKS on the Atterberg limits of the samples. From Figure 5, it is observed that LL and PL decrease, whereas PI increases almost linearly with an increase in the percentage of addition of PKSA and PPKS content. This demonstrates that the palm kernel shell, either in ash or pulverized, has similar effects on the Atterberg limits of the shale sample.

It can be seen from Figure 5 that the liquid limit (LL) decreases slightly from 56.6 to $53.43 \%$ and $56.4 \%$ at $0-12 \%$ of PPKS and PKSA, respectively. The plastic limit (PL) also decreases slightly from 35.31 to $32.39 \%$ and $32.1 \%$, with a corresponding increase in PI from 21.29 to $23.31 \%$ and $21.44 \%$ at $0-12 \%$ of PPKS and PKSA, respectively. The reduction in the LL and plastic limit (PL) of the shale could be explained by the cementitious properties of PKSA and PPKS content, which resulted from the initial flocculation agglomeration between the clay particles present in the shalePKS mixtures. These aggregation and cementation properties of the shale-PKSA and PPKS matrix lead to the closure of interconnected pores, thereby decreasing the void ratio.

As seen in Figure 5, the results demonstrate that the values of LL and PL of the treated shale sample are higher 
TABLE 1: Geotechnical properties of the untreated shale.

Parameters

Natural moisture content (\%)

Specific gravity $(\mathrm{g})$

Liquid limit, LL (\%)

Plastic limit, PL (\%)

Plasticity index, PI (\%)

AASHTO classification

Unconfined compressive strength, UCS $(\mathrm{kPa})$

Hydraulic conductivity $(\mathrm{m} / \mathrm{s})$

Volumetric shrinkage strain, VSS (\%)

Maximum dry density $\left(\mathrm{Mg} / \mathrm{m}^{3}\right)$
Values

20.00

2.24

56.60

35.31

21.29

A-7-5

$375.10^{\mathrm{a}}, 426.20^{\mathrm{b}}$

$5.24 \times 10^{-7 \mathrm{a}}, 0.43 \times 10^{-7 \mathrm{~b}}$

$14.93^{\mathrm{a}}, 16.03^{\mathrm{b}}$

$1.45^{\mathrm{a}}, 1.51^{\mathrm{b}}$

${ }^{\mathrm{a}}$ Results from West African Standard (WAS). ${ }^{\mathrm{b}}$ Results from Modified AASHTO Standard (MAS).

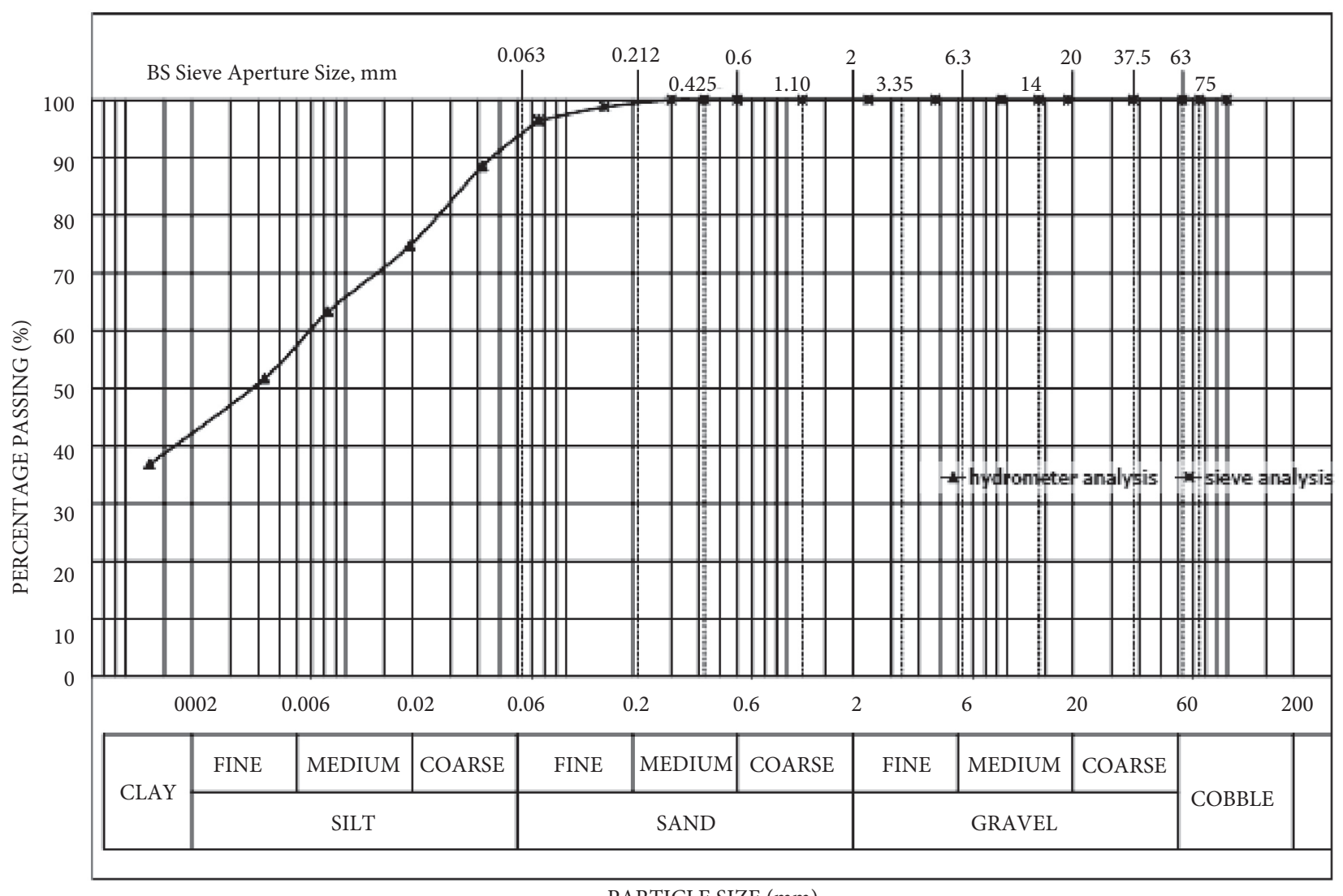

Figure 3: The particle size distribution of the sampled shale.

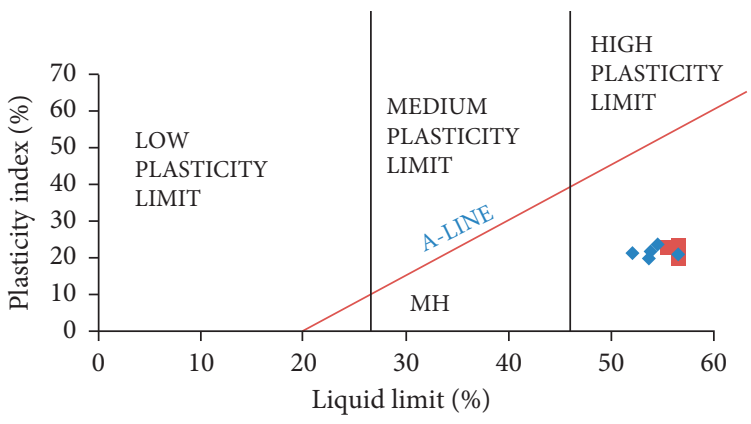

- Shale+PPKS

- Shale+PKSA

Figure 4: The Casagrande chart of the sampled shale. 


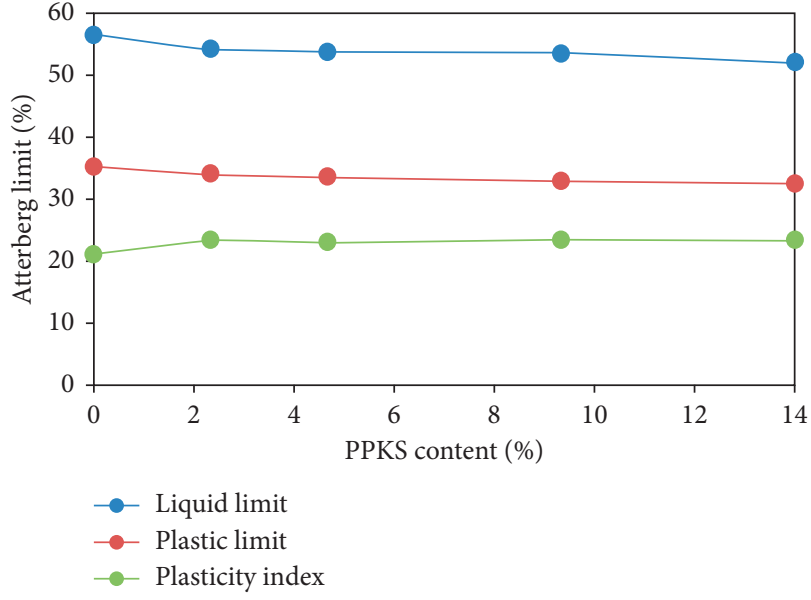

(a)

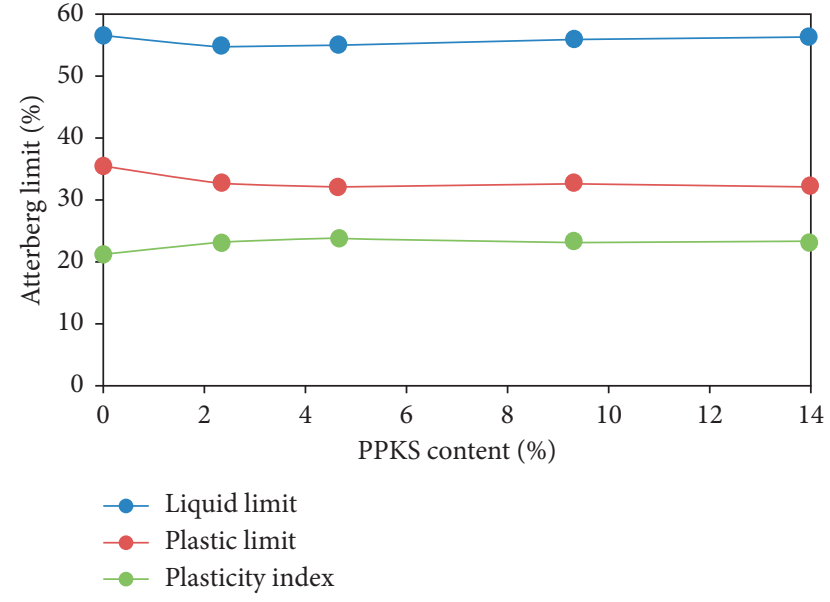

(b)

FIgURe 5: Atterberg limits versus PPKS and PKSA for the treated shale.

than $\mathrm{LL} \geq 30 \%$ and $\mathrm{PL} \geq 15 \%$ as recommended by TCEQ [27]. Significantly, the plasticity index of the treated shale sample is also higher than $7 \%$, therefore meeting the condition of the suitability of soils as landfill liners (Hamdi and Srasra [28].

5.3. Compaction Characteristics. Figure 6 shows the maximum dry density (MDD) of shale samples containing $0 \%$, $2 \%, 4 \%, 8 \%$, and $12 \%$ of PPKS and PKSA. As can be seen from Figure 6, there is clear evidence that MDDs of the soilPPKS and PKSA matrix compacted at the MAS and WAS compactive efforts decrease almost linearly with an increase in the percentage of addition of the stabilizers. Significantly, the MDD of each stabilizer falls within a small range for each compactive energy. In the case of MAS compactive energy, the MDD at $0 \%$ of PKSA and PPKS content was $1.51 \mathrm{Mg} / \mathrm{m}^{3}$, which increased to 1.53 and $1.51 \mathrm{Mg} / \mathrm{m}^{3}$ (at $2 \%$ of both stabilizers), respectively, and then decreased constantly as the content of PKSA increases. Conversely, the MDD of the treated shale decreases constantly with an increase in the stabilizer content for WAS compactive energy. Figure 7 shows the relationship between the optimum moisture content (OMC) and PKSA and PPKS of the compacted shale samples. From Figure 7, it can be seen that the results exhibited general trends of increase in OMC with an increase in the percentage of addition of PPKS and PKSA for both compactive energies. The optimum moisture content (OMC) for WAS ranges from 20.7 (at $0 \%$ of the stabilizers) to 33.3 and $26.0 \%$ at $12 \%$ of PKSA and PPKS, respectively, whereas the OMC for MAS ranges from $19.92 \%$ (at $0 \%$ of the stabilizers) to 24.68 and $24.51 \%$ at $12 \%$ of PKSA and PPKS, respectively. However, WAS compactive effort shows a more pronounced increase in OMC for both stabilizers.

As described above, the initial increase in MDD could be attributed to the pozzolanic effect of the stabilizers and probably due to the initial flocculation and agglomeration of shale particles caused by a possible cation exchange reaction between the shale-PKSA and PPKS matrix. Thus, these

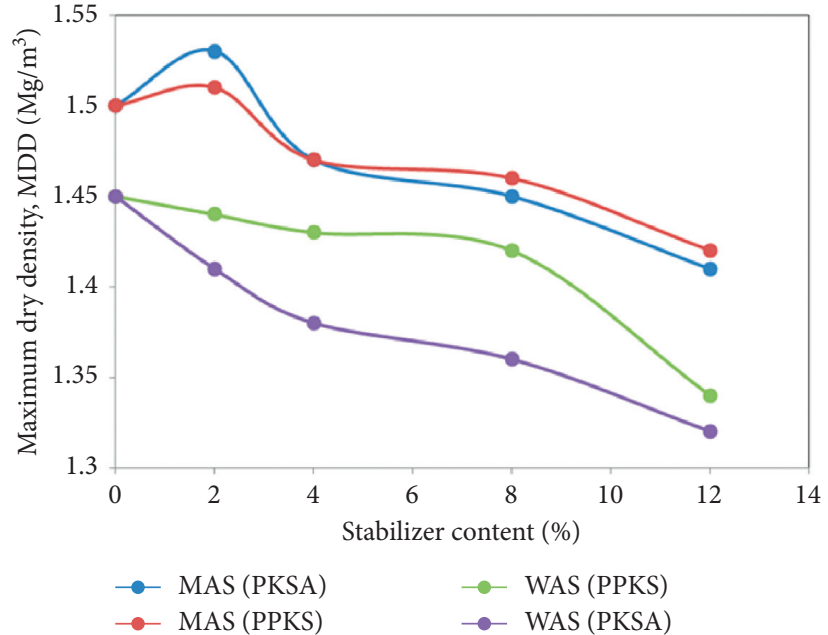

FIgURE 6: Maximum dry density (MDD) versus PKSA and PPKS for the treated shale at MAS and WAS methods.

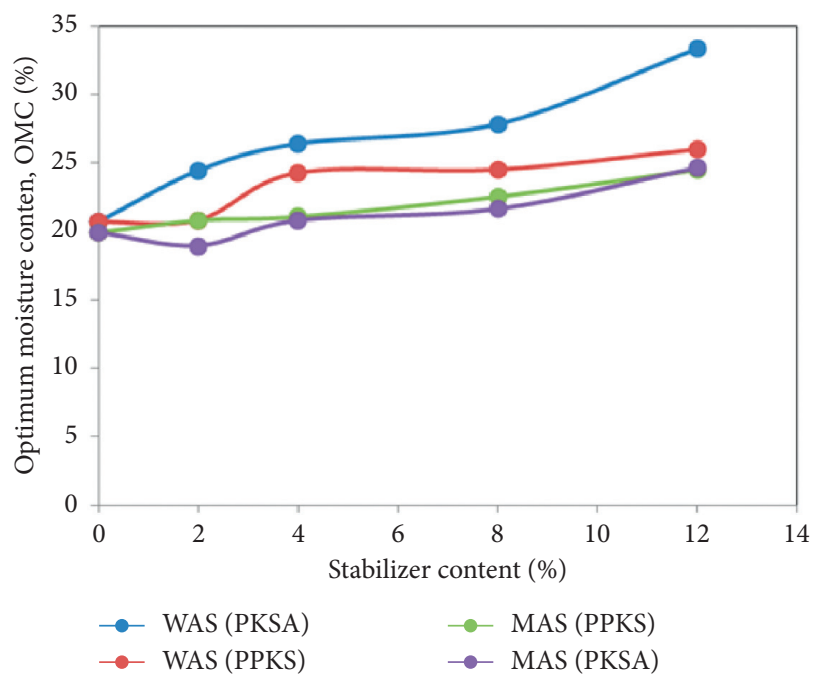

FIgURE 7: Optimum moisture content (OMC) versus PKSA and PPKS for the treated shale at MAS and WAS methods. 
effects lead to an increase in volume and a decrease in dry density. The constant decrease in MDD after 2\% addition of the stabilizers is owing to the effects of coating the shale sample with PKSA and PPKS, which consequently increases the voids and density, as confirmed by Ako and Yusuf [16]. It was also possible due to the low specific gravity of PKSA and PPKS of 1.19 and 1.22, respectively, which may have substituted the high absorption rate of the soil and the addition of finer particles, which requires more water to hydrate $[29,30]$.

The corresponding increase in OMC could be a result of an increase in the surface area of particles caused by an increase in the volume of PKSA and PPKS content in the mixture, which required more water to lubricate the entire mix matrix to enhance compaction, due to hydration reactions of the matrix as explained by Ako and Yusuf [16]. The increase in OMC and its corresponding decrease in MDD with the increase in the percentage of addition of the stabilizers have significant geotechnical effects as compaction can easily be achieved with wet shale. Consequently, there is less need for the shale to be dried to lower moisture content prior to compaction in the landfill. However, a mixture of $2 \%$ of the stabilizers, mostly at MAS compactive effort, satisfied the criteria for landfill liner as Amadi et al. [31] and Tuncan et al. [32] recommended soils with MDD $\geq 1.50 \mathrm{Mg} / \mathrm{m}^{3}$ to be applied as landfill liner.

5.4. Hydraulic Conductivity $(k)$. It is well known that when clay-shale soil is used as liners subjected to water pressure in the landfills, it causes an increase in hydraulic conductivity as time passes, which in turn may lead to instability as a result of the excessive expansion. For this reason, the choice of adequate natural soil with a hydraulic conductivity of the order of $10^{-7}-10^{-9} \mathrm{~ms}^{-1}$ for attenuation is needed for the construction of a landfill [1]. Therefore, the hydraulic conductivity of the shale samples treated with PKSA and PPKS compacted using the WAS and MAS compactive energy was determined based on ASTM D5084-1991 procedures as described by Hamdi and Srasra [28]. The hydraulic conductivity $k$ was calculated using the following equation:

$$
k=2.303 \frac{a L}{A t} \log \frac{h_{1}}{h_{2}},
$$

where $k$ is the hydraulic conductivity $\left(\mathrm{ms}^{-1}\right), A$ is the crosssectional area of the specimen $\left(\mathrm{m}^{2}\right), a$ is the cross-sectional area of the standpipe $\left(\mathrm{m}^{2}\right), L$ is the length of the specimen $(\mathrm{m})$, and $h$ is the head difference $(\mathrm{m})$, at time $t$.

Figure 8 shows the relationship between the hydraulic conductivity of compacted shale samples and varying percentages of PSKA and PPKS content. As presented in Table 1, the hydraulic conductivities of the untreated sample compacted by WAS and MAS compactive energy were $5.24 \times 10^{-7} \mathrm{~m} / \mathrm{s}$ and $2.43 \times 10^{-7} \mathrm{~m} / \mathrm{s}$, respectively. In contrast, the hydraulic conductivity of the shale samples treated with PKSA ranged from $1.51 \times 10^{-7}$ at $2 \%$ to $1.25 \times 10^{-7} \mathrm{~m} / \mathrm{s}$ at $12 \%$ under WAS and $3.91 \times 10^{-7}$ at $2 \%$ to $9.91 \times 10^{-8} \mathrm{~m} / \mathrm{s}$ at $12 \%$ for MAS. In contrast, the hydraulic conductivity of the compacted shale samples treated with PPKS varies from $2.05 \times 10^{-7}$ at $2 \%$ to $1.18 \times 10^{-7} \mathrm{~m} / \mathrm{s}$ at $12 \%$ for WAS and $1.64 \times 10^{-7}$ at $2 \%$ to $8.47 \times 10^{-8} \mathrm{~m} / \mathrm{s}$ at $12 \%$ for MAS.

As shown in Figure 8, the hydraulic conductivity of the samples treated with PPKS decreases gradually with an increase in the percentages of the stabilizer content. The decrease in the hydraulic conductivity could be explained by reducing the pore size. Conversely, the hydraulic conductivity of the samples treated with PKSA stabilizer increased slightly higher than that of untreated shale sampled at $2 \%$ for MAS and $4 \%$ for WAS. These slight increases may result from the porous nature of the PKSA particles, which in turn lead to a high specific surface, consequently resulting in the adsorption of a large number of hydrated cations and water molecules, thereby contributing to the increase in hydraulic conductivity. Moreover, the excessive PKSA content can change the soil matrix, which also can cause an increase in flocculation, as established by Osinubi and Eberemu [15]. It can also be seen that the treated sample (Figure 8) has lower values of hydraulic conductivity than those of the untreated sample, as presented in Table 1. As seen in Figure 8, the results demonstrate that the hydraulic conductivity of treated samples with $4 \%$ of the PPKS stabilizer and above falls within $\leq 1 \times 10^{-7} \mathrm{~ms}^{-1}$ [1]; therefore, it meets the condition of the suitability of soils as landfill liners. This proves that the addition of PKS to the soil used as a landfill liner will resist an increase in the hydraulic conductivity caused by contaminants, as it positively influences the suitability of the soil as a landfill liner. Moreover, it functions as an attenuating layer enabling the leachate to percolate slowly downwards, simultaneously undergoing attenuation by precipitation, adsorption, and exchange processes within the landfill [26].

5.5. Compressive Strength of the Treated Shale. The standard uniaxial compression tests were performed on shale samples containing $0 \%, 2 \%, 4 \%, 8 \%$, and $12 \%$ of PPKS and PKSA cured for 3 days to determine the compressive strength of the treated shale using West African Standard (WAS) and Modified AASHTO Standard (MAS) compactive energy level. The relationship between the compressive strength of the shale and the percentage of addition of PPKS and PKSA content is shown in Figure 9. Figure 9 shows that the strength of the compacted shale was enhanced by adding $4 \%$ of PKSA and PPKS contents and a further increase in the addition of PPKS and PKSA contents beyond $4 \%$ tends to reduce the strength of the compacted samples steadily. It is also observed, in Figure 9, the strengths of the treated shale compacted at MAS were generally 50 times greater than those of the WAS. Therefore, it is noted that the maximum strengths of 380.40 and $448.70 \mathrm{kPa}$ were recorded at $4 \%$ of PKSA with MAS and WAS compactive efforts, respectively. The subsequent increase in the strength of the treated shale at $4 \%$ can be attributed to the pozzolanic effect of the PKSA and PPKS in which the lime provides a conducive environment for the dissolution of silicates and aluminates in the soil, hence reacting with $\mathrm{Ca}+2$ cations to form the cementation process through the hydration process [33]. The 


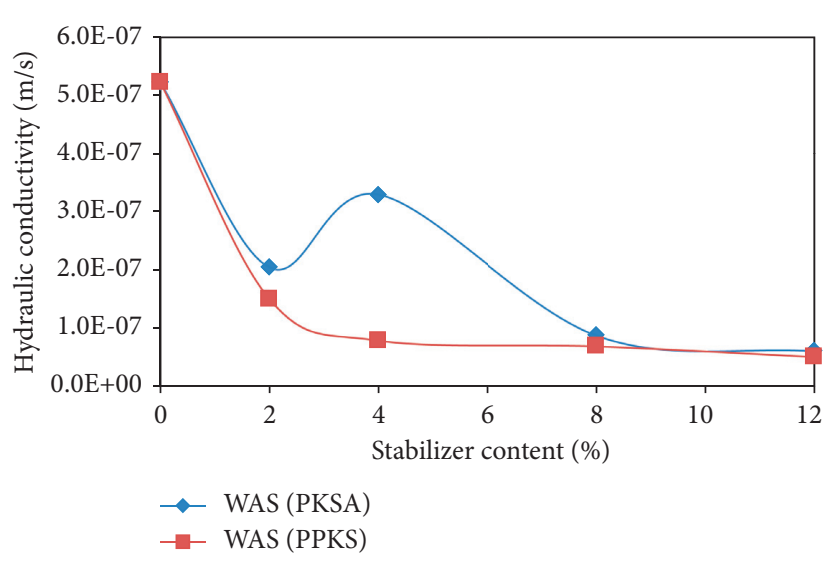

(a)

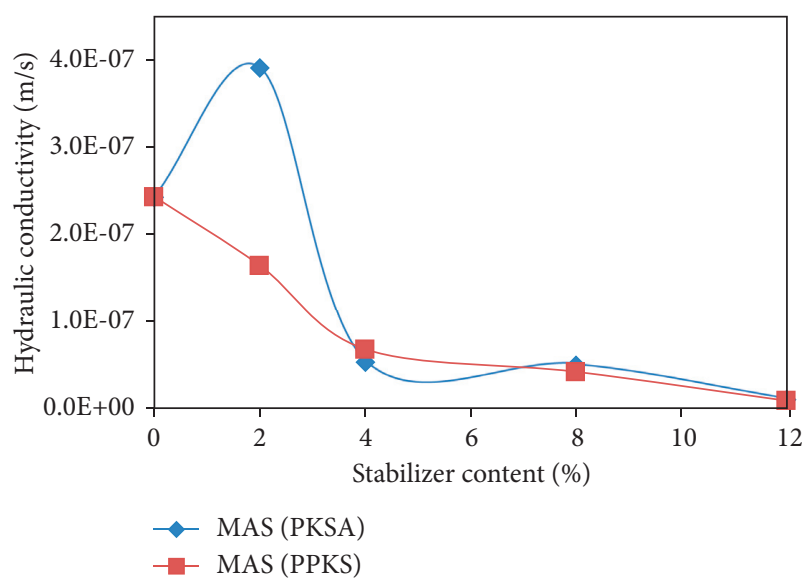

(b)

FIgURE 8: Hydraulic conductivity versus PKSA and PPKS for the treated shale at MAS and WAS methods.

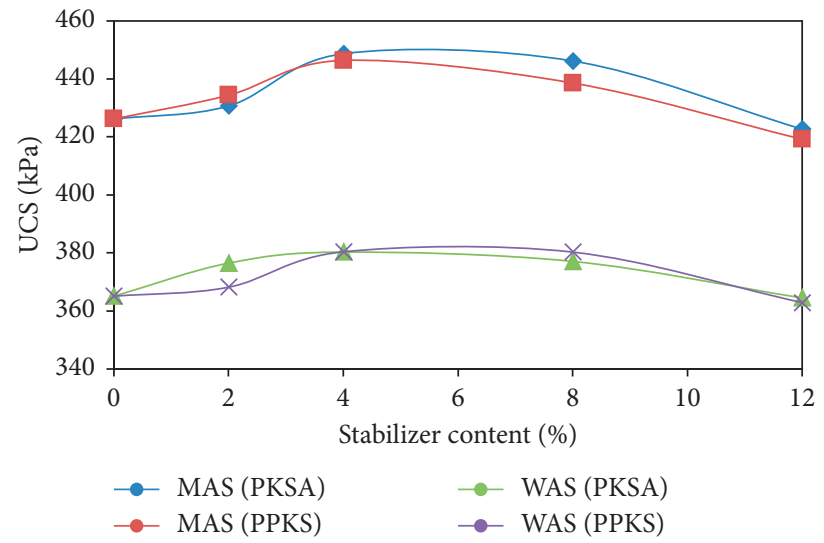

FIgURE 9: Compressive strength of the treated shale samples at MAS and WAS compactive efforts.

decline in the strength by a further increase in the addition of PPKS and PKSA contents is owing to the dilution influence of the stabilizers on the shale, which reduces the pozzolanic reactions. In a related study, the use of a PKSA has proved to be highly effective for cementitious application in the soil, as reported by Ako and Yusuf [16]. Significantly, the result showed that the strength of the treated shale at both compactive efforts is greater than $200 \mathrm{kPa}$, maximum bearing strength of a landfill liner as proposed by Daniel and $\mathrm{Wu}$ [34]; therefore, it satisfied the condition of the suitability of soils as landfill liners.

5.6. Volumetric Shrinkage Strain (VSS). In landfill engineering, it is essential to understand the shrinkage characteristics of liner material in order to control cracks. Desiccation cracking is often a problem in landfills, which in turn can cause an increase in hydraulic conductivity [35]. Therefore, it is essential to prevent excessive shrinkage cracking due to changes in moisture content that occur during the lifetime of the landfill. This is mainly because the presence of cracks in landfill cover provides potential pathways for water infiltration, increasing the generation of waste leachate and eventually increasing the risk of soil and groundwater contamination, as demonstrated by Miller et al. [35]. To overcome this problem, there is a need to ensure sufficient strength for the stability of engineering projects worldwide [36], including landfills during their construction and operation stage [37].

Consequently, the drying shrinkage test was performed on shale samples with the addition of containing $0 \%, 2 \%, 4 \%$, $8 \%$, and $12 \%$ of PPKS and PKSA contents. Prior to the test, the shale-PPKS and PKSA matrix were cured for a day, thereafter, extruded from the compaction molds, and then allowed to air-dry for a period of 30 days in the laboratory to assess the effect of desiccation-induced shrinkage on the material used as a landfill liner. The volumetric shrinkage upon drying was measured by extruding cylindrical specimens and then compacted using the WAS and MAS energy levels. Measurements of diameter and heights for each specimen were taken with the aid of a vernier caliper accurate to $\pm 0.03 \mathrm{~mm}$. The average diameter and heights were used to compute the volumetric shrinkage strain.

Figure 10 describes the effect of PKSA and PPKS as cementitious material on the drying shrinkage of the mixture at $0,5,10,15,20,25$, and 30 days, respectively. It can be 


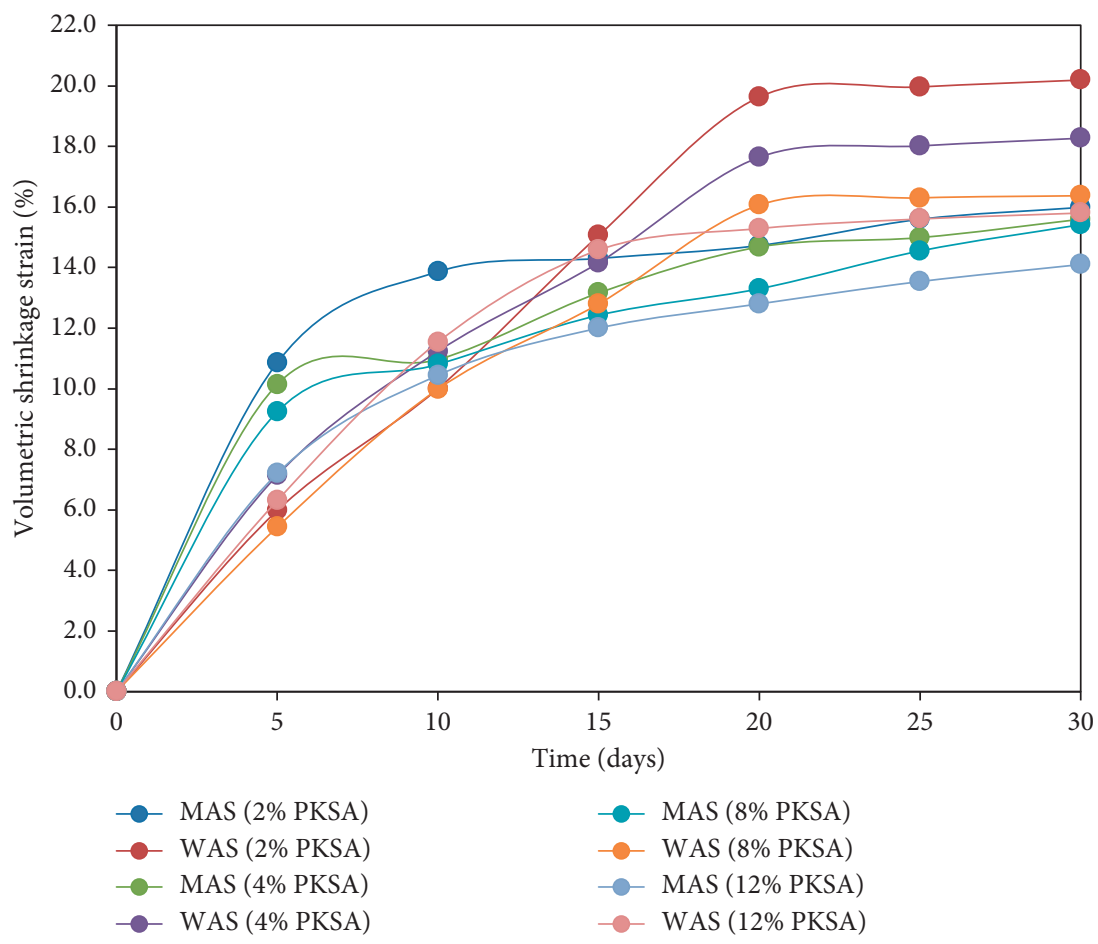

(a)

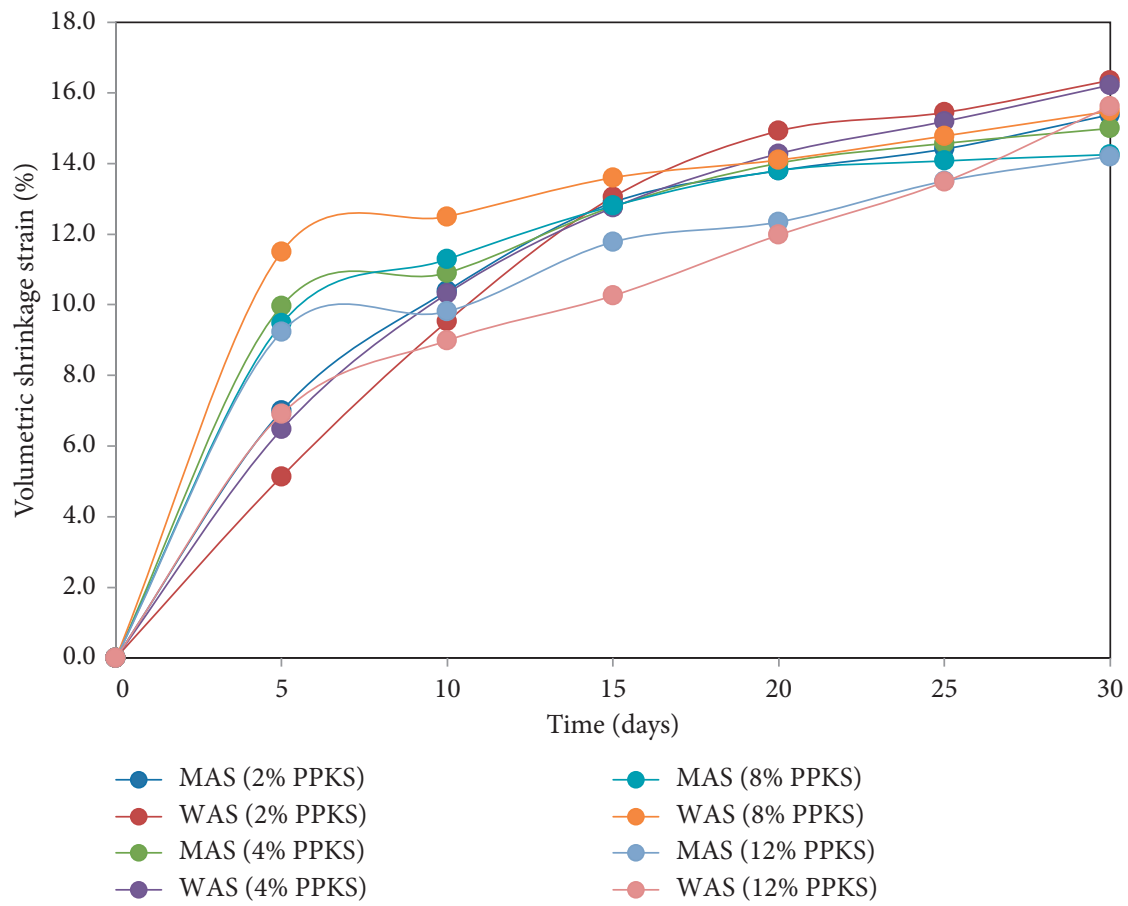

(b)

FIGURE 10: Volumetric shrinkage strain with time.

seen that there is a sharp increase in VSS within the first five to fifteen days of drying, mostly with WAS compactive energy level. Thereafter, the trends of increment become more or less constant with time. Figure 11 shows correlations between mass of the shale-PPKS and PKSA matrix and time at 30 days. As shown in Figure 11, the mass of the treated shale decreases gradually as PKSA and PPKS contents increase with time of drying. The decreases in the 


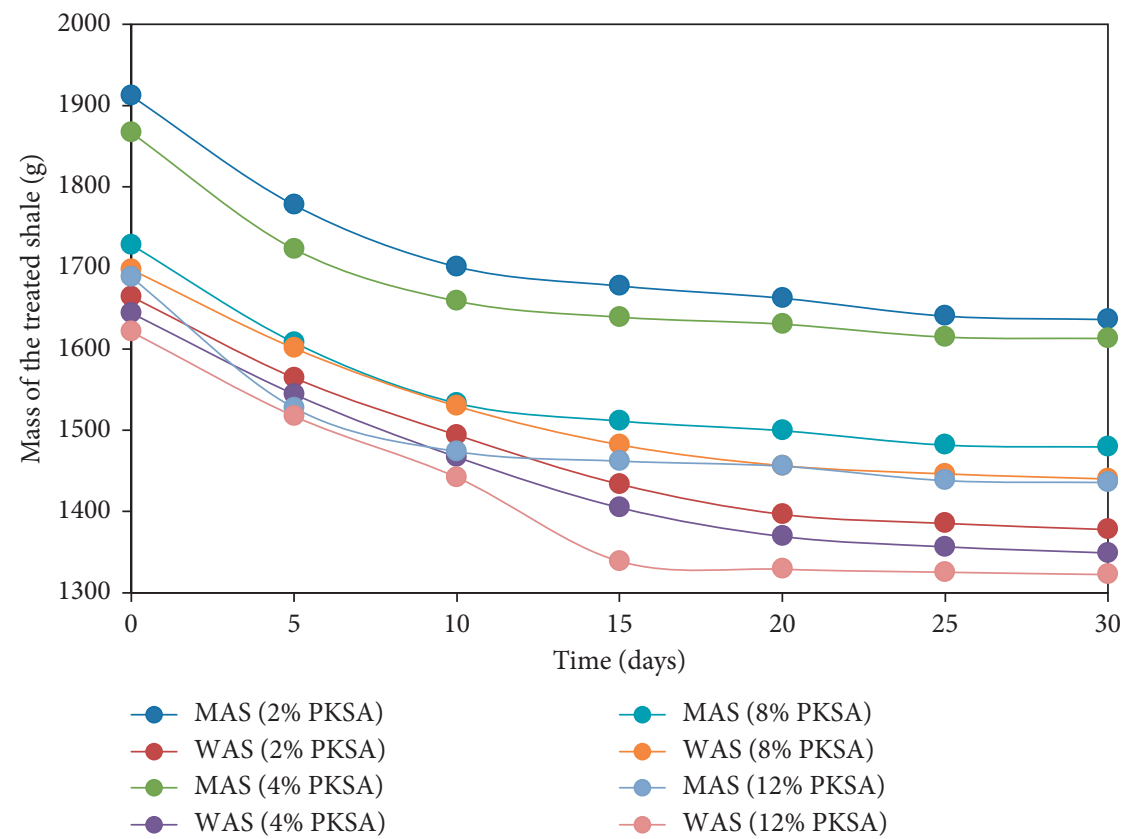

(a)

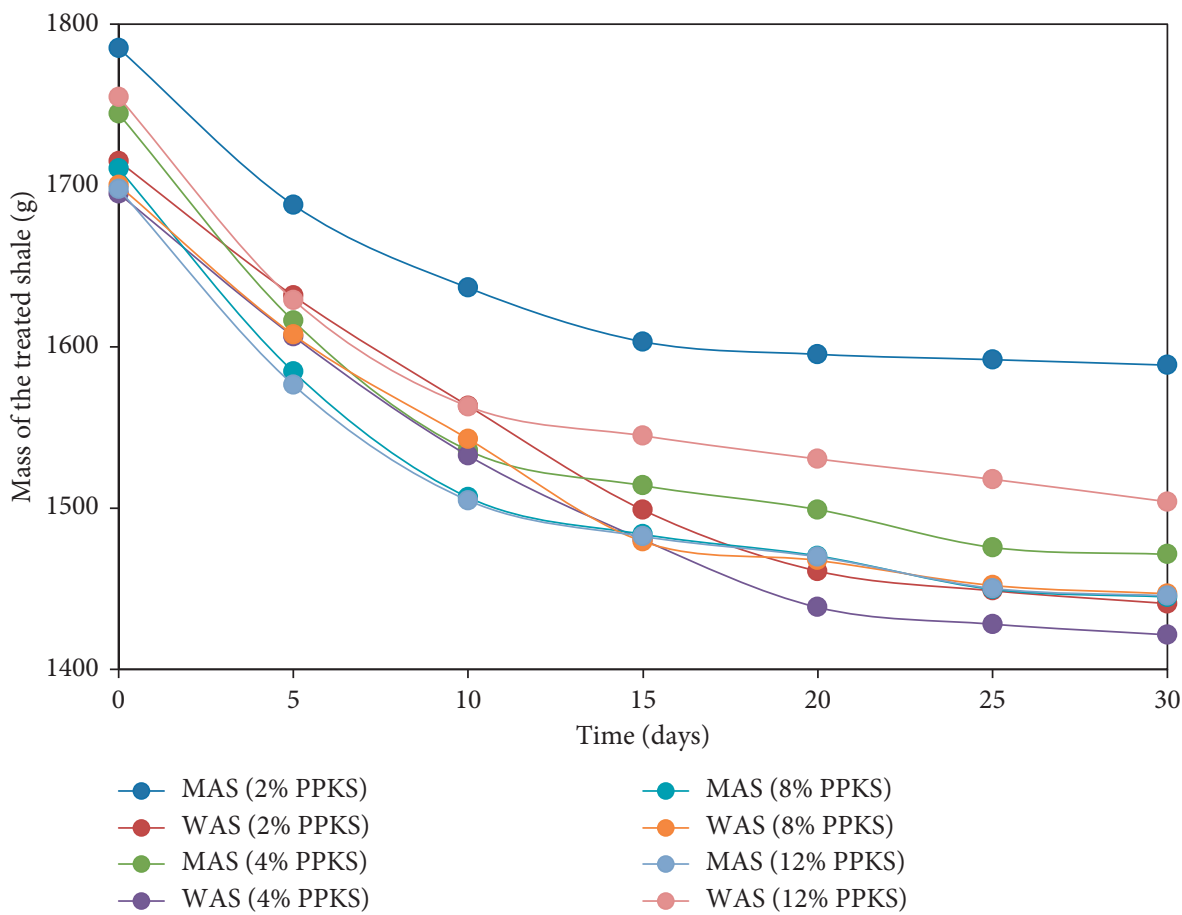

(b)

FIGURE 11: Relationship between the mass of the treated shale and time.

trends of mass are similar for each compactive energy level. Clearly, drying shrinkage is proportional to the molding water content.

The relationship between VSS and varying percentages of PKSA and PPKS for the two compactive efforts was shown in Figure 12. From Figure 12, it can be observed that the shrinkage of the shale decreases with the rising content of PKSA and PPKS. Although the decreasing trends were more clear for MAS compactive effort, the decrease in drying shrinkage is owing to the finer particles of PKSA and PPKS, 


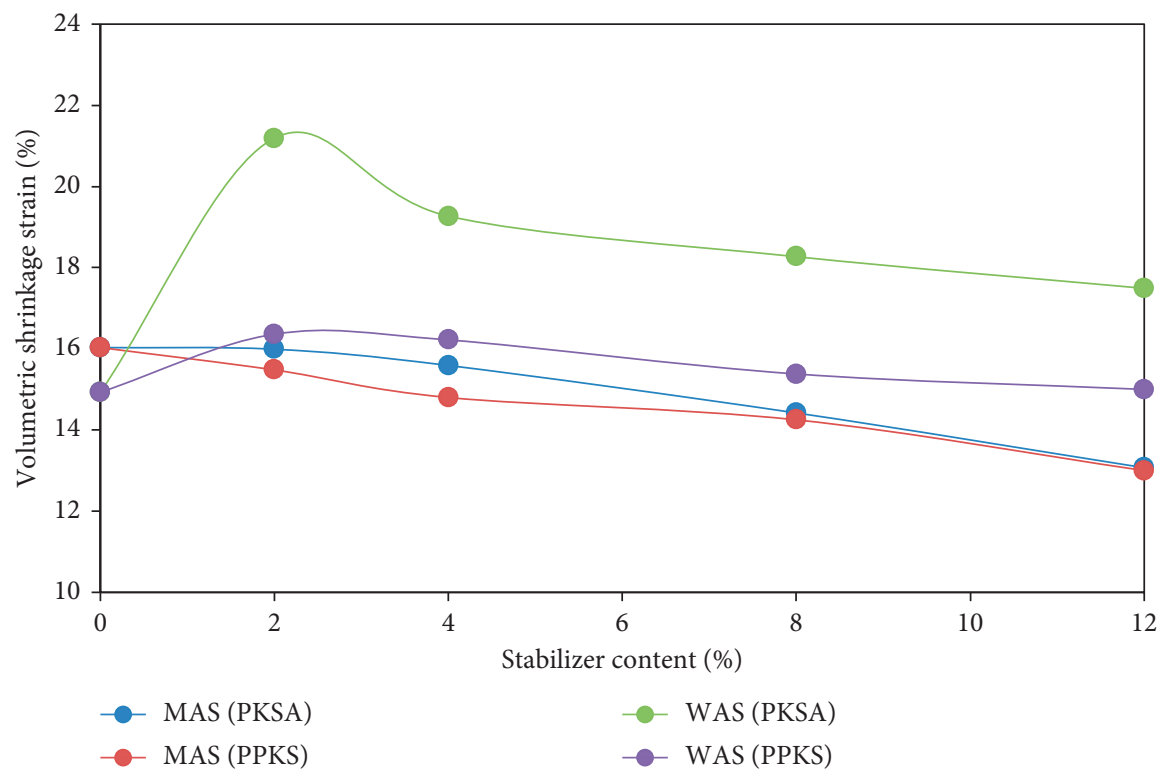

FIGURE 12: Volumetric shrinkage strain of the treated shale at MAS and WAS compactive efforts.

which act as a filler and interlocked the pores, which consequently slow the rate of shrinkage in the treated shale. According to Tay et al. [37], shrinkage decreases as the amount of cement replacement material (such as ash), which builds up the mechanical interlocking in the pores, increases.

\section{Conclusions}

This study determined the mechanical properties of compacted shale treated with varying percentages of palm kernel shell ash (PKSA) and pulverized palm kernel shell (PPKS) using West African Standard (WAS) and Modified AASHTO Standard (MAS) for compactive efforts to ascertain their stability as landfill liners barrier in waste containment applications. Thus, the following conclusions were drawn from the study:

(1) From the grain size analysis and the Atterberg limit, the shale was classified as A-7-5, with percentage finer grains, which constituted materials, mainly clay, silty, and sand. The Atterberg limit tests revealed that the liquid limit (LL) and plastic limit (PL) decrease with an increase in plasticity index (PI) as the percentage of addition of PKSA and PPKS content increases.

(2) The results also revealed that an optimum moisture content (OMC) value increases, whereas the maximum dry density (MDD) and hydraulic conductivity decrease with rising in the percentage of addition of PKSA and PPKS content for both compactive efforts.

(3) The drying shrinkage of the treated shale samples reduced with an increase in the percentage of addition of PKSA and PPKS content. Overall, the experimental results infer that the blend of the compacted shale-PPKS matrix, mostly $4 \%$ of the stabilizer at MAS compactive effort, satisfied the condition of the suitability of soils as landfill liners for both compactive energy levels. Therefore, it can be concluded that the addition of $4 \%$ of PPKS to the compacted shale sample is the optimum replacement. Moreover, the addition of palm kernel shells to the compacted shale used as landfill liners can also serve as alternative means of reducing wastes generated from the local milling industry to ensure the significant social, economic, and environmental impact of the waste.

\section{Data Availability}

The data used in supporting the results of our study are included within the manuscript.

\section{Conflicts of Interest}

The authors declare that there are no conflicts of interest regarding the publication of this article.

\section{Acknowledgments}

The authors wish to acknowledge the efforts of the staff at the Laboratory of Civil Engineering Department, University of Ibadan and Soil Laboratory, Department of Geology, Federal University of Technology, Akure, Nigeria, in conducting the experiments for this study.

\section{References}

[1] A. Allen, "Containment landfills: the myth of sustainability," Engineering Geology, vol. 60, pp. 3-19, 2000.

[2] J. Wagner, "Incentivizing sustainable waste management," Ecological Economics, vol. 70, no. 4, pp. 585-594, 2011.

[3] M. El-Fadel, E. Bou-Zeid, W. Chahine, and B. Alayli, "Temporal variation of leachate quality from pre-sorted and 
baled municipal solid waste with high organic and moisture content," Waste Management, vol. 22, no. 3, pp. 269-282, 2002.

[4] M. A. Warith and R. N. Yong, "Landfill leachate attenuation by clay soil," Hazardous Waste and Hazardous Materials, vol. 8, no. 2, pp. 127-141, 1991.

[5] U. N. Ngoc and H. Schnitzer, "Sustainable solutions for solid waste management in Southeast Asian countries," Waste Management, vol. 29, no. 6, pp. 1982-1995, 2009.

[6] K. Kayabaly, "Engineering aspects of a noval landfill liner material: bentonite amended natural zeolite," Engineering Geology, vol. 46, pp. 105-114, 1997.

[7] D. Cazaux and G. Didier, "Field evaluation of hydraulic performances of geosynthetic clay liners by small and largescale tests," Geotextiles and Geomembranes, vol. 18, no. 2-4, pp. 163-178, 2000.

[8] E. A. M. Yahia, A. A.-R. Amer, Y. A. L.-A. Mohammed, Q. Ahmed, and Al-R. Abdul-Hamid, "Assessment of crushed shales for use as compacted landfill liners," Engineering Geology, vol. 80, pp. 271-281, 2005.

[9] C. Di Maio, L. Santoli, and P. Schiavone, "Volume change behaviour of clays: the influence of mineral composition, pore fluid composition and stress state," Mechanics of Materials, vol. 36, no. 5, pp. 435-451, 2004.

[10] L. A. Guerrero, G. Maas, and W. Hogland, "Solid waste management challenges for cities in developing countries," Waste Management, vol. 33, no. 1, pp. 220-232, 2013.

[11] M. K. Widomski, W. Stępniewski, and R. Horn, "Sustainability of compacted clays as materials for municipal waste landfill liner," Middle Pomeranian Scientific Society of the Environment Protection, vol. 18, pp. 439-454, 2016.

[12] D. Q. Zhang, S. K. Tan, and R. M. Gersberg, "Municipal solid waste management in China: status, problems and challenges," Journal of Environmental Management, vol. 91, no. 8, pp. 1623-1633, 2010.

[13] M. O. A. Mtallib and G. M. Bankole, "The improvement of the index properties and compaction characteristics of lime stabilized tropical lateritic clays with rice husk ash (RHA) admixtures," EJGE, vol. 16, pp. 983-996, 2011.

[14] J. R. Oluremi, S. I. Adedokun, and O. M. Osuolale, "Stabilization of poor lateritic soils with coconut husk ash," International Journal of Engineering Research and Technology, vol. 1, no. 8, 2012.

[15] K. J Osinubi and A. O. Eberemu, "Hydraulic conductivity of lateritic soil treated with blast furnace slag," Electronic Journal of Geotechnical Engineering, vol. 11, pp. 1-16, 2006.

[16] T. Ako and I. T. Yusuf, "Utilization of palm kernel shell ash as a stabilizer of lateritic soil for road construction," Epistemic in Science," Engineering and Technology, vol. 6, no. 1, pp. 423-433, 2016.

[17] K. Obeng, K. AG. Ocran, and D. Anaba, "Palm Kernel Shell as fuel for burning bricks," Building Resources Information, vol. 2, no. 5, pp. 131-136, 1997.

[18] I. N. Ali and U. M. Umar, "An appraisal of spatial distribution of solid waste disposal sites in kano metropolis, Nigeria," Journal of Geoscience and Environment Protection, vol. 5, pp. 24-36, 2017.

[19] K. A. Ayuba, L. A. Manaf, A. H. Sabrina, and S. W. N. Azmin, "Current status of municipal solid waste management practise in FCT abuja," in Research Journal of Environmental and Earth Sciences, F. C. T Abuja, Ed., vol. 5, no. 6, pp. 295-304, 2013.
[20] C. M. A. Iwegbue, G. E. Nwajei, J. E. Ogala, and C. L. Overah, "Determination of trace metal concentrations in soil profiles of municipal waste dumps in Nigeria," Environmental Geochemistry and Health, vol. 32, no. 5, pp. 415-430, 2010.

[21] A. R. Allen, "Sustainability in landfilling: containment versus dilute and disperse," in 8th Congress of the International Association of Engineering Geologists, D. P. Moore and O. Hungr, Eds., vol. 4, pp. 2423-2431, Vancouver, Canada, 1998.

[22] C. S. Nwajide, Geology of Nigeria's Sedimentary Basins, p. 565, CSS Bookshops, Lagos, 2013.

[23] A. C. Amagu, S. N. Eze, J. Kodama, and M. O. Nweke, "Geological and geotechnical evaluation of gully erosion at Nguzu Edda, Afikpo Sub-basin, southeastern Nigeria," Journal of Environment and Earth Science, vol. 8, no. 12, pp. 148-158, 2018.

[24] Bsi 1377-1, Methods of Test for Soils for Civil Engineering Purposes (BS 1377: 1990, Parts 1 to 9), p. 406, British Standards Institute, London, 1990.

[25] Aashto M145-91, Standard Specifications for Classification of Soils and Soil-Aggregate Mixtures for Highway Construction Purposes, American Association of State Highway and Transportation Officials, Washington, Wash, USA, 1991.

[26] L. Y. Li and F. Li, "Heavy metal sorption and hydraulic conductivity studies using three types of bentonite admixes," Journal of Environmental Engineering, vol. 127, no. 5, pp. 420-429, 2001.

[27] Texas Commission on Environmental Quality Tceq, Guidance for Liner Construction and Testing for a Municipal Solid Waste Landfil, p. 37, Waste Permits Division, Municipal Solid Waste Permits Section, Texas, 2017.

[28] N. Hamdi and E. Srasra, "Hydraulic conductivity study of compacted clay soils used as landfill liners for an acidic waste," Waste Management, vol. 33, no. 1, pp. 60-66, 2013.

[29] N. N. Nik Daud, A. S. Muhammed, and A. M. Kundiri, "Hydraulic conductivity of compacted granite residual soil mixed with palm oil fuel ash in landfill application," Geotechnical \& Geological Engineering, vol. 35, no. 5, pp. 1967-1976, 2017.

[30] O. Adewale, A. Segun, and A. Ariyo, "Structural evaluation of the effect of pulverized palm kernel shell (PPKS) on cementmodified lateritic soil sample," American Journal of Civil Engineering, vol. 5, no. 4, pp. 205-211, 2017.

[31] A. N. Amadi, I. A. Okunlola, C. J. Eze, M. O. Jimoh, C. Unuevho, and F. Abubakar, "Geotechnical assessment of clay deposits in Minna, North-Central Nigeria for use as liners in sanitary landfill design and construction," American Journal of Environmental Protection, vol. 3, no. 3, pp. 67-75, 2015.

[32] A. Tuncan, M. I. Onur, K. Akpinar, and M. Tuncan, "Use of sepiolite and zeolite mixtures as a landfill liner," International Journal of Wine Research, vol. 6, no. 1, p. 197, 2016.

[33] M. Alhassan, "Potentials of rice husk ash for soil stabilization," AUJ T, vol. 11, no. 4, pp. 246-250, 2008.

[34] D. E. Daniel and Y. K. Wu, "Compacted clay liners and covers for arid sites," Journal of Geotechnical Engineering, vol. 119, no. 2, pp. 223-237, 1993.

[35] C. J. Miller, H. Mi, and N. Yesiller, "Experimental analysis of desiccation crack propagation in clay liners," Journal of the American Water Resources Association, vol. 34, no. 3, pp. 677-686, 1998.

[36] C. A. Amagu, C. Zhang, J. Kodama et al., "Displacement measurements and numerical analysis of long-term rock slope 
deformation at higashi-shikagoe limestone quarry, Japan," Advances in Civil Engineering, vol. 2021, Article ID 1316402, 15 pages, 2021.

[37] Y. Y. Tay, D. I. Stewart, and T. W. Cousens, "Shrinkage and desiccation cracking in bentonite-sand landfill liners," Engineering Geology, vol. 60, no. 1-4, pp. 263-274, 2001. 